\title{
The provision of pharmaceutical advice improves patient vaccination status
}

\author{
Joerg FUCHS.
}

\begin{abstract}
${ }^{*}$
Aim: To increase vaccination rates in the wealthy industrial nation of Germany. For a variety of reasons there is a substantial deficit in the number of individuals who receive vaccinations in comparison with other industrialized countries. Methods: In Autumn 2003, a regional vaccination consultation was initiated over a five-week period. Individuals involved in the study provided general information, including their age, health status, and vaccination records, and received an extensive consultation in a pharmacy in Jena, Germany. Participants were provided with a written overview of their vaccination status. After approximately five weeks, the vaccination status of each individual was recorded.

Results: 312 of 2500 patients received intensive vaccination education based on their accompanying vaccination documentation. Older individuals, who are known for having the largest vaccination gap in Germany, represented the highest percentage of people who used this service. The five most commonly required vaccinations had increased significantly, five weeks after the consultation. These vaccination rate increases included diphtheria, which rose from 55.8 to $71.2 \%$, tetanus, which rose from 73.1 to $86.5 \%$, influenza, which rose from 46.5 to $74.7 \%$, pneumococcal, which rose from 32.4 to $62.8 \%$, and tick-borne encephalitis, which rose from 31.9 to $42.4 \%$ (all $p \leq 0.008$ ). Conclusions: Well structured vaccination consultations help to raise vaccination rates. Thus, pharmacies should consider offering and implementing this preventive measure so as to lower the rates of preventable disease and to save costs.
\end{abstract}

Keywords: Vaccination. Counseling. Patient Education. Pharmacists. Germany.

\footnotetext{
*Joerg FUCHS. PAINT-Consult, Jena, Germany and the Department for Drug Regulatory Affairs at the Institute of Pharmacy, University of Bonn. (Germany)
}

\begin{abstract}
RESUMEN
Objetivo: Incrementar las tasas de vacunación en el industrial país de Alemania. Por diversos motivos hay un déficit substancial en el número de personas que reciben vacunas comparado con otros países industrializados.

Métodos: En otoño de 2003, se inició una consulta regional de vacunaciones por un periodo de cinco semanas. Las personas que se incluyeron en el estudio proporcionaron información general que incluía edad, estado de salud y registros de vacunaciones, y recibieron una consulta intensa en una farmacia de Jena, Alemania. Se proporcionó a los participantes una revisión escrita de su estado de vacunación. Después de cinco semanas se registró el estado de vacunación de cada persona. Resultados: 312 de los 2500 pacientes recibieron educación intensa sobre las vacunas basada en la documentación de vacunación que acompañaban. Los ancianos, que se sabe que tienen la mayor brecha en vacunación, representaron el mayor porcentaje de personas que usaron este servicio. Cinco semanas después de la consulta, las cinco vacunas más utilizadas habían aumentado significativamente. Estos aumentos de tasas de vacunación incluyeron difteria, que se elevó del $55,8 \%$ a $71,2 \%$, tétanos, que se elevó del $73,1 \%$ a $86,5 \%$, gripe, que se elevó del $46,5 \%$ al $74,7 \%$, neumococo, del $32,4 \%$ al $62,8 \%$, y encefalitis de las garrapatas, que se elevó del 31,9\% a 42,4\% (todas $\mathrm{p} \leq 0.008$ ).

Conclusiones: Consultas sobre vacunaciones bien estructuradas ayudan a elevar las tasas de vacunación. Por tanto, las farmacias deberían considerar ofrecer e implantar esta medida preventiva para reducir las tasas de enfermedades prevenibles y ahorrar costes.
\end{abstract}

Palabras clave: Vacunación. Consejo. Educación de pacientes. Farmacéuticos. Alemania.

\section{INTRODUCTION}

Of all public health preservation measures, vaccination is one of the most effective. If vaccination rates are sufficiently high it is possible to eliminate diseases regionally and even worldwide. Two exemplary models, smallpox and poliomyelitis, support the strength of mass vaccination. The entire American continent, Europe, and the Pacific are now considered poliomyelitis free. ${ }^{1}$ 
In addition to containing or eliminating infectious agents, vaccination also saves $\operatorname{costs}^{2,3}$, which is particularly important in this era of low worldwide funding for health issues. The Nichol study group at the Veteran Affairs Medical Center (Minneapolis, MN, USA), determined that for every elderly person who is vaccinated against influenza, 42.9 US dollars is saved. ${ }^{4}$ Pneumococcal vaccination provides an even higher economic saving than influenza vaccination, since patients with pneumococcal disease usually require substantial hospital treatment. A study of 1898 patients revealed a savings of 147 USD per year, for each patient vaccinated against pneumococcal disease. ${ }^{5}$ The protection provided by pneumococcal vaccination persists over six years, with the exception of asplenia patients $^{6}$, so the financial advantage over this period accumulates to 882 USD per patient. Additional studies have confirmed this financial saving potential. ${ }^{7-9}$

Although vaccinations are cost saving measures that successfully prevent disease, vaccination is not obligatory in Germany. In addition, German health insurance companies do not take sufficient action to implement the recommendations published by the German Vaccination Commission ("Ständige Impfkommission" [STIKO]). Although these recommendations provide criteria for successful vaccination prevention, such as the general cost absorption of standard vaccinations like diphtheria and tetanus, Germany still has insufficient vaccination rates compared to other industrial nations. The relatively high rate of vaccination that begins in pre-school, declines as people get older. Thus, the largest vaccination gaps exist in adults and older citizens. ${ }^{10-13}$

In November 2001, the rate of pneumococcal vaccination was $22 \%$ in the new Federal Republic States (East Germany; former GDR) and in the old Federal Republic States only $7 \%$ were recommended as vaccine targets by the German Vaccination Commission (STIKO). ${ }^{11}$ In contrast, $50 \%$ of Americans between ages 65 and 74, and $61 \%$ of people over 75 years were already vaccinated against pneumococcal disease in 1999. ${ }^{14}$ The vaccination rates for other diseases like influenza, tetanus, and diphtheria are also unsatisfactory in Germany. ${ }^{12,13}$ In the Netherlands and France, for example, people over 65 have significantly higher rates of vaccination against influenza.

The aim of this study was to increase vaccination rates in the wealthy industrial nation of Germany

\section{METHODS}

In order to increase the vaccination rates of citizens in Jena, a vaccination consultation, was set up in a pharmacy called "Apotheke am Nollendorfer Hof" from September 15th to October 17th, 2003. Awareness of this consultation was raised using flyers, posters, and newspaper advertisements, and pharmaceutical personnel actively approached people once they had entered the pharmacy. During the consultation period patients were informed about the benefits and possible risks associated with vaccination and asked to obtain any from their physician that they had not yet received. Individuals who had brought their vaccination records to the pharmacy received a computer-aided vaccination consultation. Patients were provided with an overview of their personal vaccination status according to Germany's 2003 vaccination recommendations (valid at the time). ${ }^{16}$ This contained the following information:

- Date of last vaccination

- Date of next booster vaccination

- Evaluation of vaccination status

The printed vaccination status in DIN-A6-page format $(105 \times 148.5 \mathrm{~mm})$ was attached to the vaccination record of every person who received comprehensive advice. When participants did not possess a vaccination record, which was a frequent occurrence, a new record was issued by the pharmacy, ensuring that each person left with a valid vaccination record. Loose sheets with supporting vaccination documents were attached to the vaccination record. A minimum of five weeks after the vaccination consultation, individuals were asked to resubmit their vaccination records to the pharmacy or were consulted by telephone to redetermine their vaccination status.

\section{RESULTS}

During the five-week consultation period, approximately 2,500 people were informed about vaccination. 312 of these participants received a documented comprehensive vaccination consultation based on their vaccination record. The intensive vaccination consultation lasted an average of nine minutes (minimum: two minutes; maximum: 22 minutes). The 312 participants were between the ages of 4 and 98 at the time of the study (average age: 58 years). $62.3 \%$ of people were 60 years or older (Table 1). Approximately two thirds of this group were female $(62.2 \%)$ and the majority lived in Jena (89.8\%).

\begin{tabular}{|l|c|c|}
\hline \multicolumn{3}{|c|}{ Table 1. Age distribution of the 312 people who } \\
received intensive vaccination advice \\
\hline \multirow{2}{*}{ Age (years) } & \multicolumn{2}{|c|}{ Frequency } \\
\cline { 2 - 3 } & $\%$ & $\mathbf{n}$ \\
\hline $0-17$ & 3.2 & 10 \\
\hline $18-29$ & 7.1 & 22 \\
\hline $30-39$ & 6.8 & 21 \\
\hline $40-49$ & 10.3 & 32 \\
\hline $50-59$ & 10.3 & 32 \\
\hline $60-69$ & 38.1 & 118 \\
\hline $70-79$ & 19.4 & 60 \\
\hline $80<$ & 4.8 & 15 \\
\hline no statement & - & 2 \\
\hline
\end{tabular}

Based on their age and health status, the 312 participants were in highest need of vaccinations against diphtheria, tetanus, poliomyelitis, influenza, pneumococcal, and tick-borne encephalitis (Table 2). Less than $10 \%$ of the participants needed vaccinations that are not specified in Table 2 . During the consultation, $55.8 \%$ of participants confirmed one valid vaccination against diphtheria and $73.1 \%$ confirmed one valid vaccination against 
tetanus. Based on the German Vaccination Commission STIKO target group recommendations, $32.4 \%$ of 207 susceptible patients possessed a current vaccination against pneumococcal disease and $31.9 \%$ out of 188 susceptible patients had a current vaccination against tick-borne encephalitis. Almost half of the target group had already received an influenza vaccination in 2002 and prior to consultation in 2003 (46.5\%; $\mathrm{n}=282$ ) (Table 3). Elderly participants had the worst vaccination regard overall, while $25.9 \%$ of individuals between ages 40 and 59 were sufficiently vaccinated (Table 4).

From November 2003 to April 2004, the number of patients who had obtained the required vaccinations from their physician was determined. There was a significant increase in vaccination rate following pharmaceutical consultation for each of the specified vaccinations (Table 3 ). The target group's pneumococcal vaccination rate almost doubled to $62.8 \%$, and the influenza vaccination rate increased to $74.7 \%$. The rates of increase were somewhat smaller for the three other vaccinations, which only showed a 10 to $15 \%$ rise, however each case was still significant $(p \leq 0.008)$. At the time of consultation, 39 of the 312 participants $(12.5 \%)$ had already completed all the necessary vaccinations. This had increased to $32.9 \%$ five months later. A further $36.1 \%$ of participants received some of the required vaccinations while the remaining $31 \%$ did not receive any vaccinations.

\begin{tabular}{|l|c|c|}
\hline $\begin{array}{l}\text { Table 2. Fraction of the vaccinations most frequently } \\
\text { needed by the 312 intensively advised participants }\end{array}$ \\
\hline \multirow{2}{*}{ Vaccination } & \multicolumn{2}{|c|}{$\begin{array}{c}\text { Necessary vaccination } \\
\text { indication } \\
\text { (n =312 participants) }\end{array}$} \\
\cline { 2 - 3 } & $\%$ & $\mathbf{n}$ \\
\hline Diphtheria & 100 & 312 \\
\hline Tetanus & 100 & 312 \\
\hline Poliomyelitis & 100 & 312 \\
\hline Influenza & 90.4 & 282 \\
\hline Pneumococcal & 66.3 & 207 \\
\hline Tick-borne encephalitis & 60.2 & 188 \\
\hline Hepatitis B & 18.3 & 57 \\
\hline Hepatitis A & 15.7 & 49 \\
\hline
\end{tabular}

\begin{tabular}{|c|c|c|c|c|}
\hline \multirow[t]{2}{*}{ Vaccination } & \multicolumn{3}{|c|}{ Vaccination rate } & \multirow{2}{*}{$\begin{array}{c}\text { Significant } \\
\text { differences } \\
\text { between before } \\
\text { and after advice } \\
(\mathrm{p})\end{array}$} \\
\hline & $\begin{array}{c}\text { East German } \\
\text { reference } \\
{[\%]}\end{array}$ & $\begin{array}{c}\text { Before advice } \\
{[\%]}\end{array}$ & $\begin{array}{c}\text { After advice } \\
{[\%]}\end{array}$ & \\
\hline Diphtheria & 9 & 55.8 & 71.2 & $p<0.001$ \\
\hline Tetanus & 43 & 73.1 & 86.5 & $p<0.001$ \\
\hline Influenza & 46 & 46.5 & 74.7 & $p<0.001$ \\
\hline Pneumococcal & 22 & 32.4 & 62.8 & $p<0.001$ \\
\hline Tick-borne encephalitis (FSME) & unknown & 31.9 & 42.4 & $p=0,008$ \\
\hline
\end{tabular}

\begin{tabular}{|c|c|c|}
\hline Age (years) & Sufficient vaccination status (\%) & Insufficient vaccination status (\%) \\
\hline $18-39$ & 20.9 & 79.1 \\
\hline $40-59$ & 25.9 & 74.1 \\
\hline $60<$ & 8.8 & 91.2 \\
\hline
\end{tabular}

\begin{tabular}{|l|c|c|}
\hline \multicolumn{3}{|l|}{$\begin{array}{l}\text { Table 5. Reasons given by 159 participants for not following pharmacy vaccination recommendations } \\
\text { (multiple reasons also applied) }\end{array}$} \\
\hline $\begin{array}{l}\text { Reasons why vaccinations were } \\
\text { not applied: }\end{array}$ & $\begin{array}{c}\text { Frequency of all given } \\
\text { comments (n) }\end{array}$ & $\begin{array}{c}\text { Frequency of comments given by 159 } \\
\text { participants, who had received } \\
\text { recommendations (\%) }\end{array}$ \\
\hline Had not managed to do it yet. & 126 & 79.2 \\
\hline $\begin{array}{l}\text { Did not want one or more } \\
\text { vaccinations. }\end{array}$ & 19 & 11.9 \\
\hline $\begin{array}{l}\text { Physician said it was not } \\
\text { necessary. }\end{array}$ & 17 & 10.7 \\
\hline Other reasons & 10 & 6.3 \\
\hline
\end{tabular}

159 participants specified reasons for not completing their vaccinations. $129(79.2 \%)$ reported that they did not have enough time to receive the vaccinations or had forgotten about it. All of these individuals stated an intention to follow the pharmacist's recommendations (Table 5). 19 patients $(11.9 \%)$ later rejected at least one recommended vaccination. Vaccination refusal was not recorded in these cases, since they had received one or more vaccinations after the consultation. In addition, their visits to the pharmacy suggested that they had an interest in optimizing their vaccination status.

The physicians of 17 individuals $(10.7 \%)$ rejected the vaccination recommendations as futile, even though they are based on the German vaccination commission STIKO guidelines. Eight patients were told that diphtheria vaccination was no longer necessary and six patients between ages 63 and 71, who were willing to be vaccinated, did not 
receive the pneumococcal vaccination because their physician said that it was unnecessary or that they were too young to receive it. Two patients over 75 years were refused the influenza vaccination since they used the coagulation inhibitor, phenprocoumon. Their physicians did not consider that an indication existed instead of a contraindication. $^{5}$

\section{DISCUSSION}

The interest that was shown in receiving vaccination consultations reflected confidence in pharmaceutical services. Since physicianss are the only individuals allowed to administer vaccinations in Germany, pharmacies are a good place to provide vaccination advice.

Based on the demographic composition of the 312 consultation participants, elderly people, who represent the largest vaccination gap in Germany ${ }^{11}$, were the largest group to be reached by the services provided in this study. It is also a positive sign that a large number of women were informed, since they are in a position as family health managers, to actively convey any information they receive to their families. However, the scope of patient interest shown in this study was only achieved with a comprehensive publicity campaign before and during the consultation period. In an age of information overflow, activities such as this are required to raise awareness about vaccination prevention.

The significant increase in the rate of vaccination against the five most important standard vaccinations, diphtheria, tetanus, influenza, pneumococcal, and tick-borne encephalitis, is a particularly positive sign. Since Germany is part of the polio free European continent, booster vaccination following basic immunization against poliomyelitis is no longer recommended for everyone. ${ }^{6}$ Thus, this vaccination is not specified in Table 3. Minor increases in diphtheria and tetanus as compared to influenza and pneumococcal disease, were the result of significantly higher initial values. Vaccination against tick-borne encephalitis was usually accomplished only after follow-up vaccination against other diseases. Vaccination protection was expected to increase further in 2004. The two newly classified tick-borne encephalitis risk areas in neighbouring districts, recently characterized as the Saale-Holzland-Kreis ${ }^{17} 2002$ and Saale-Orla-Kreis ${ }^{16} 2003$, should also increase vaccination rates against this disease.

The frequently quoted "vaccination weariness" in Germany cannot be confirmed on the basis of this vaccination consultation. Eventhough healthoriented people with positive vaccination attitudes used this service, the most frequent reasons stated for not following the vaccination recommendations were lack of memory and ignorance about which vaccinations are needed and in which intervals revaccination is necessary. The latter mainly concerned people over 60 , since they always need additional vaccinations against influenza and pneumococcal, in addition to diphtheria and tetanus. ${ }^{6}$ A study of influenza vaccination was accomplished in Germany in November 2001. This confirmed a predominantly positive attitude toward vaccination. $78 \%$ of 730 people endorsed the influenza vaccination, and only $9 \%$ declined the vaccination. $^{12}$

It is unacceptable for physicians to refuse the administration of vaccinations that are recommended for patients (Table 5)

\section{CONCLUSIONS}

The eminent existence of large vaccination deficits in Germany emphasizes the need for greater effort from all sides of the health service. Pharmacies with more involvement in future vaccination prevention can help to close vaccination gaps that are more prevalent in Germany than other industrial nations. This is a reasonable course to follow since it presents the possibility of sensitizing elderly people, as well as those who rarely consult their physicians for vaccination.

\section{References}

1. Global Polio Eradication Initiative: The poliomyelitis history. http://www.polioeradication.org/history.asp (accessed 24th July 2006).

2 Rychlik R, Heinen-Kammerer T, Rusche H, Piercy J, Scuffham P, Zöllner Y. Kosteneffektivität der Prophylaxe und Behandlung von Influenza. Dtsch Med Wochenschr 2003;128:2267-70.

3 Bridges CB, Thompson WW, Meltzer MI, Reeve GR, Talamonti WJ, Cox NJ, Lilac HA, Hall H, Klimov A, Fukuda K. Effectiveness and cost-benefit of influenza vaccination of healthy working adults - a randomized controlled trial. JAMA 2000;284:1655-63.

4 Nichol KL, Goodman M. Cost effectiveness of influenza vaccination for healthy persons between ages 65 and 74 years. Vaccine 2002;20:21-4.

5 Nichol KL, Baken L, Wuorenma J. The health and economic benefits associated with pneumococcal vaccination of elderly persons with chronic lung disease. Arch Intern Med 1999;159:2437-42.

6 Robert Koch Institut: Empfehlungen der Ständigen Impfkommission (STIKO) am Robert-Koch-Institut / Stand: Juli 2005. Epidemiologisches Bulletin 2005;30:257-72.

7 Ament A, Baltussen R, Duru G, De Graeve RBD, Örtqvist A, Jönsson B, Verhaegen J, Gaillat J, Christie P, Salazar Cifre A, Vivas D, Loiseau C, Fedson DS. Cost-effectiveness of pneumococcal vaccination of older people: a study in 5 western European countries. Clinical Infectious Diseases 2000;31:444-50.

8 Sisk JE, Moskowitz AJ, Whang W, Lin JD, Fedson DS, McBean AM, Plouffe JF, Cetron MS, Butler JC. Cost-effectiveness of vaccination against pneumococcal bacteraemia among elderly people. JAMA 1997;278:1333-9. 
9 Gable CB, Holzer SS, Engelhart L, Friedman RB, Smeltz F, Schroeder D, Baum K. Pneumococcal vaccine - efficacy and associated cost savings. JAMA 1990;264:2910-5.

10 Dippelhofer A, Meyer C, Kamtsiuris P, Rasch G, Reiter S, Bergmann KE. Erste Ergebnisse zum Impfstatus aus der Pilotphase des Kinder- und Jugendgesundheitssurveys, Bundesgesetzblatt - Gesundheitsforsch - Gesundheitsschutz 2002;4:332-7.

11 Reiter S. Ausgewählte Daten zum Impf- und Immunstatus in Deutschland, Bundesgesetzblatt - Gesundheitsforsch Gesundheitsschutz 2004;12:1144-50.

12 Robert Koch-Institut: Teilnahme an Influenza- und Pneumokokken-Schutzimpfung - Bundesweite Querschnittsstudie zur Situation in der Saison 2001 / 2002. Epidemiologisches Bulletin 2002;16:127-31.

13 BKK Bundesverband: BKK-Umfrage zeigt: Jeder zweite Erwachsene noch nie gegen Diphtherie geimpft, jeder fünfte noch nie gegen Wundstarrkrampf, http://www.bkk.de/bkk/pressemitteilungen/powerslave,id,2,nodeid,15,ps_lo,60.html (accessed16th October.2004).

14 Centers for Disease Control and Prevention (CDC). Influenza and pneumococcal vaccination levels among persons aged 65 years - United States, 1999. MMWR 2001;50:532-7.

15 Kronemann M, Paget WJ, van Essen GA. Influenza vaccination in Europe: an inventory of strategies to reach target population and optimise vaccination uptake. Eurosurveillance 2003;8:130-38.

16 Robert Koch-Institut: Empfehlungen der Ständigen Impfkommission (STIKO) am Robert Koch-Institut / Stand: Juli 2003. Epidemiologisches Bulletin 2003;32:245-54.

17 Robert Koch-Institut: Risikogebiete der Frühsommer-Meningoenzephalitis (FSME) in Deutschland - Bewertung des örtlichen Erkrankungsrisikos ermöglicht gezielte Prävention für Exponierte. Epidemiologisches Bulletin 2002;26:212-5. 